\title{
Impact of Brand Community in Social Networks on Customer Loyalty to Brand (Case Study: Customers of the Tejarat Bank)
}

\author{
${ }^{1}$ Fatemeh Goli, ${ }^{* 2}$ Naser Yazdani \\ ${ }^{1}$ MSC Student of Business Administration, Shahed University , ${ }^{* 2} \mathrm{Ph} . \mathrm{D}$, Assistant Professor, Shahed \\ University, Tehran, Iran, \\ *2Email:n.yazdani@shahed.ac.ir
}

\section{Received: 13 $^{\text {th }}$ February 2018, Accepted: 20 $^{\text {th }}$ February 2018, Published: 28th February 2018}

\begin{abstract}
In today's challenging environments where businesses and firms are increasingly competing with each other, they cannot compete with outdated marketing philosophy in this environment. The emergence and expansion of communication technologies has made social networks one of the most important tools for effective participation in the field of competition. This advancement forces firms to apply their efforts to improve their position in the minds of the customer by eliminating location and time problems. The present paper aims to investigate the impact of brand community in social networks on customer loyalty in the Tejarat Bank. This paper examines the impact of brand community in social networks on customer loyalty to the brand in the Tejarat Bank. The data were collected using a survey method of questionnaire distribution among 301 customers of Tejarat Bank in 20 branches of Tehran city and it has been analyzed using partial least squares method. The results of the findings show that community in social networks has a positive and significant effect on customer loyalty to brand in Tejarat Bank, but the effect of satisfaction on behavioral loyalty has not been confirmed. The purpose of the present research is to help banks in providing better and high quality services by using new marketing methods and increasing customer loyalty by supplying their consent and keep absorbed customers at a low cost.
\end{abstract}

Keywords: Brand Community, Social Networking, Customer Loyalty, Trust, Customer Satisfaction

\section{Introduction}

The banking system has a very heavy responsibility in a market-driven economy and is one of the most important components of the country's economy. The growth and flourishing of the economic structure of the countries is closely linked to the working practices of the banking institutions. Optimum banking activities and the effective use of marketing tools to realize their goals; including exploiting capital and equipping it with various economic activities and the general state of the economy are very effective. Since the 1960s, many Iranian banks have sought to implement marketing principles to a limited extent. However, considering the relatively small profits of the banking system in Iran and the inefficiency and effectiveness of the banks' branches in the field of marketing and relations with customers, Iranian banks are heavily in need of marketing, and the banking system in Iran requires a change in this regard. Now social networks are not just a place to connect with friends, but an online space for fans of brands that interact with each other and also become familiar with brands. Given this potential, social networks are a place to build their own brand pages to attract and retain customers and increase their brand loyalty(1). Brand loyalty is synonymous with concepts and terms such as "repurchase ", "preference," "commitment," and "following(2). According to Divot and others (2003), loyalty has a sense of affection and customer dependency on the organization (quoted by(3)). Brand loyalty means the repetition of shopping which the reason is psychological behavior, in other words, repurchasing is not an optional reaction but a result of psychological, emotional and normative factors (4)

One of the important factors that affects brand loyalty is the brand's effect(5). The brand effect is the potential brand impact on the positive emotional response of the consumer when using the product (service). In other words, the brand's effect can be defined as the consumer's emotional response to a brand as a result of having an experience (6-8).

The brand expresses the relationship between the customer and the product, and a successful brand can relate the company and the customer. According to the results of the Champaign and McDonald studies (1992), brand success is $80 \%$ of consumer relationship and $20 \%$ of cost effective, which implies the importance of brand relationships(9). Relationship with the brand stems from the customer's mentality of the brand image(10) .

In the information age, consumers are looking for information through the Internet and collecting information about their products to be purchased, which mainly affects their purchasing habits and shares their experiences in this environment(11). The global use of the Internet (electronic media) and its applications have shaken all aspects of human life from business and education to social activities (12). One of these applications is social networks sites.

Social networks are a group of people who have specific interests(13).A social network is a social structure of individuals or organizations that 
communicate with one or more of them to share common values and goals(14).

According to some studies, social networking can ask users for their needs in order to upgrade their services(15). Social networking users for word-ofmouth advertising for companies are an ideal goal. Their participation in online social networks allows them to use the words in their business messages and naturally they want to share their information. Lee (2007) believes that more than half of users have used products before joining social networks and online social networks users are interested in seeing the company's profile (16).

The emergence of commercial communities in social media transforms consumers from passive recipients to a very active information receiver social actors(17) .

The brand community is created by relationships among individuals, including brand, product, customer, company and social networks. That's why we believe that social media can create such an environment that offers interactions among the elements called the brand community (18). Marketing on social networks to attract customers' attention and achieve them at a lower cost, and more acceleration and better understanding of the customer is the most important route for marketers because the results of the research indicate that the useful and popular content on social networks effect on brand loyalty(19) .

In this research, brand community in social networks based on customer-driven principles has been investigated and its impact on brand satisfaction, trust and brand effectiveness has been studied. So this research seeks to answer this question: How is the impact of brand community in social networks on customer loyalty to the brand?

\section{Theoretical Fundamentals and Research Background}

Globalization has defined the process of integration of people on the ground in such a way that no events are considered purely local. According to this definition today, with the globalization of other communications one-way communication between customers and organizations has changed from oneway and parallel to complex bilateral communication. The banking system has a very heavy responsibility in a market-driven economy and is one of the most important components of the country's economy. The growth and flourishing of the economic structure of the countries is closely linked to the working practices of the banking institutions. Optimum banking activities and the effective use of marketing tools to realize their goals, including exploiting capital and equipping it with various economic activities and the general state of the economy are very effective.
When banks increase their advertising, a more favorable image of the brand is created in the minds of customers that ultimately leads to customer satisfaction and loyalty(20).

Now social networks are not just a place to connect with friends, but an online space for fans of brands that interact with each other as well as get familiar with brands. Given this potential, social networks are a place to build their own brand pages to attract and retain customers and increase their brand loyalty(1). The word brand is used as an act containing dual capacity with positive implications such as proprietary proof, sign of quality, etc.(21) .

Marketing on social networks to attract customers' attention and achieve them at a lower cost and more acceleration and better understanding of the customer is the most important route for marketers because the research's results indicate that the useful and popular contents on social networks affect brand loyalty (19).

Proof of the positive relationship between social networks and brand loyalty requires the focus of managers on social networking and how members participate in increasing brand loyalty(22).

Brand community provides an opportunity for customers who interact with each other, although this opportunity is offered to customers, companies can encourage and support their customers to increase their loyalty in this way(23). Brand community is customer- oriented (24), and a method through which branding brings consumers to the brands and customers to other users(25).

When customers join a brand community based on social network, they are constantly exposed to the content and experiences of customers from other products (8). This interaction means engaging in conversations about product information such as usage, technology, and market information for that product. Any discussion with this title in the brand's virtual community will increase the customer's awareness of the product(26). Zhou et al. (2012) argue that the interaction of members with each other in the virtual brand community is the basis for the creation and development of social relationships in such communities (27).

Consumers have a particular incentive to use each brand, in addition, companies have different motivations for their brand's community, and customers are also a great source of ideas because ultimately, by improving the current product or announcing new demands to meet their needs, they will result in new products or services. (28) The customer, brand, product or service set reminds Moniz and Agiun triangle, which will later be added as a new relationship: customer-product, customerbrand, customer-company, and customer-other customers.(24). 
The brand expresses the relationship between the customer and the product, and a successful brand can establish the relationship between the company and the customer. According to the results of the Chematuni and McDonald studies (1992), brand success is $80 \%$ of consumer relationship and $20 \%$ of cost effective, which implies the importance of brand relationships (9)

Brand community; an opportunity for customers to meet their needs in interacting with each other; although this opportunity is offered to customers, companies can encourage and support their customers to increase their loyalty in this way(23) . The last definition is for $\mathrm{Wu}$ and colleagues: An online brand community is a set of customers with common interests in a brand that is the primary means of communication on the Internet. This community organizes a new channel for communication with customers (29).

Brand loyalty is defined as the intention to purchase, but this definition only reflects a level of customer's temporary acceptance of the brand. Hence, loyalty will be examined in two aspects of behavioral and attitude. Attitude loyalty is a level of customer commitment that comes to the brand. Behavioral loyalty refers to the customer's willingness to repurchase the brand (6). Loyalty Behavior considers loyalty to the brand as a behavior. A person who is constantly buying a brand is loyal. Brand loyalty can be defined as a behavior that is represented by a consumer of a brand in the form of repeated purchases(5). Loyalty Behavior is called brand loyalty through visible purchases in a course by Mills and Associates (2004). It also defines attitudinal loyalty based on the expression of preferences, commitment, or intent to purchase. They also define attitudinal loyalty as a commitment or intent to buy based on the expression of preferences. Morgan and Hot (1994) argue that brand confidence leads to loyalty or commitment, since trust builds highly valuable relationships. Trust can be defined as the customer's confidence and certainty, which enables the customer to rely on the seller to deliver the promised services(30). Brand trust is an important intermediate between customer behavior before and after the product purchase, which leads to long-term loyalty and the strengthening of the relationship between the two sides (5)quoted by Liu et al., 2011). Laroche et al. (2012) in a research entitled "The Effects of Social Networks on Brand, Value Creation, Brand Trust and Brand Loyalty" have shown that the formation of brand-related virtual groups in social networks increases the sense of community among members and is linked to the creation of value among members and the company. The results also show that brand loyalty increases among members of these groups, and activities related to creating value such as brand use and emotion management through trust will increase loyalty.(31)

Kabadayi et al (2012) in a research entitled "Brand Trust and Brand Effect on the Importance of Brand Loyalty Strategy" have shown that brand trust and brand efficacy will affect the brand loyalty. It has also been shown that trust in the brand and the brand efficacy are positively related.(7)

Cheung \& Thadan (2012) in a research entitled " impact of electronic word-of-mouth communication: A literature analysis and integrative model" have shown that the trust of Internet users in consumer comments and e-mail when deciding to purchase is more than their trust in traditional media and advertising(32).

Deng et al. (2010), in an article entitled " Understanding customer satisfaction and loyalty: An empirical study of mobile instant messages in China" has shown that there is a relationship between perceived value, the quality of service provided, trust, customer satisfaction, and customer loyalty. It has also shown that customer trust has been effective through satisfaction on customer loyalty(33).

Brogi et al. (2013) have shown in a research entitled "A Brand Community Based Approach to Social Networking in Fashion and Luxury Industries" that companies using Web-based technology and social networking technology and monitoring its processes effectively use the opportunities offered by brand community in social networks and increase the value of their companies and by sharing content, it affects brand loyalty(34).

The brand's effect can be viewed as a customer overall assessment of the brand's desirability or undesirability, which refers to the emotional and behavioral aspects of the brand $(8,35)$. The brand's effect describes the relationship between the consumer and the brand in a particular category, which can be considered as a general assessment of the brand by consumers. Dick \& Basu (1994) showed that brand loyalty will increase with positive emotional response. Given the brand's relationship and its sustainability, it has been argued that brand effect should be considered as an introduction to brand loyalty. And many studies $(36,37)$ have shown the relationship between the effect of brand and brand loyalty. These studies have discussed the significant effect of brand influence on attitude and behavioral loyalty (5) .

\section{Conceptual Model and Research Hypotheses}

In this research, community in social networks is considered to be a facilitating relationship between the organization and the customers, which consists of four variables and a positive relationship with them, including: the relationship of brand community in social networks-product, the 
relationship of brand community in social networkscompanies, the relationship of brand community in social networks- brand, the relationship between brand community in social networks -other customers, social networks facilitate interaction and the relationship between noted variables and brand community.

\section{Research Hypotheses}

1. Brand community affects customer product relationship.

2. Brand community affects customercompany relationship.

3 . Brand community affects customer-brand relationship.

4. Brand community affects customer relationship with other customers

Theoretically, repeated and prolonged interactions increase interpersonal trust. Customers are affected by the content provided by the brand and the comments and experiences of other customers if they use the brand. Sharing the experiences of engaging with other customers and getting the opinions of others; strengthening the four-way relationship between customer-product, customerbrand, customer-company and customer-other customers and the result of these frequent interactions will be enhanced by trust in brand. By increasing the interactions, emotional responses from customers to the brand will potentially increase. The brand's effect can be a general assessment of the customer from a brand's desirability or undesirability, which refers to the emotional and behavioral aspects of the brand $(5,8)$. This variable has three scales of a good sense, a sense of pleasure and a sense of happiness.

5. Customer-product relationship affects brand trust.

6. Customer-company relationship affects brand trust.

7. Customer-brand relationship affects brand trust.

8. Customer-to-customer relationship affects brand trust.
9. Customer-product relationship affects the brand effect.

10. Customer-company relationship affects the brand effect.

11. The brand-related relationship affects the brand effect.

12. Customer-to-customer relationship affects the brand effect.

Singh J, Sirdeshmukh (38) offer a model that Trust is an introduction to satisfaction and, consequently, an introduction to loyalty. Brand trust ultimately has a positive and significant impact on customer satisfaction(39). Satisfaction is an introduction to loyalty, which by increasing satisfaction, the brand loyalty will increase (40). According to American marketing, satisfaction is a positive reaction to a buying decision or a product and service after This is while Wilson, Persson (41) state that satisfaction has a positive impact on loyalty. In general, understanding customer benefits rather than simply understanding the benefits of an organization will increase brand confidence, which in turn increases loyalty(42).

\section{Brand trust affects customer satisfaction}

Finally, this study examines the effect of brand and customer satisfaction on attitudinal loyalty and behavioral loyalty. Many studies have confirmed the relationship of trust and loyalty; in addition to that customers who feel good with brand service are more loyal. The trust and perceived value of the firm's brand significantly increases the impact of econscience, which will also increase loyalty(43). The result of Jinn et al. also confirms the positive impact of trust on satisfaction and loyalty (44).

14. Customer satisfaction affects attitudinal loyalty.

15. Customer Satisfaction affects behavioral loyalty.

16. The effect of brand affects attitudinal loyalty.

The effect of brand affects behavioral loyalty.

Figure 1.Conceptual Model of Research

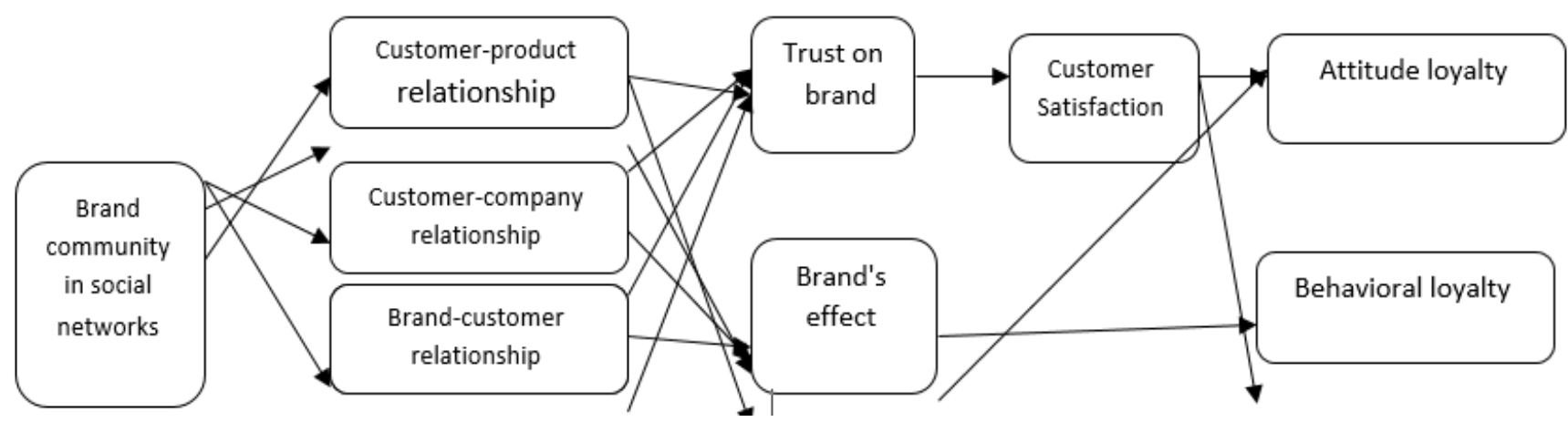

Research Methodology
The research method is based on quantitative approach. For collecting data, a standard 
questionnaire derived from previous research has been used. Indicators and research variables are defined based on previous literature. Amos software is used to analyze the data. The statistical population of this research is the clients of the Tejarat bank in Tehran who use social networks and the web for using the services. The research questions are derived from the research background and the Likert spectrum is used to quantify them (1 strongly opposed to 5 very agreeable). Cronbach's alpha was
.868, which inferred from the reliability of the questionnaire. For its validity, CVI, CVR was used, which was equal to 1 , which indicates the complete validity of the questionnaire from the experts' perspective in this field. By distributing 384 questionnaires, only 301 questionnaires were answered correctly and their data were analyzed.

The calculated Cronbach Alpha coefficients for the research variables are presented in Table (1).

Table 1.Cronbach's Alpha Coefficient for the Studied Variables

\begin{tabular}{|l|l|l|l|l|}
\hline Variable & Average & Variance & Correlation & Cronbach's alpha \\
\hline Brand Community & 33.5251 & 28.883 & .533 & .892 \\
\hline Customer -Product Relationship & 33.8379 & 28.275 & .665 & .884 \\
\hline Customer- Brand Relationship & 33.7713 & 27.933 & .720 & .880 \\
\hline Customer- Company Relationship & 33.7835 & 27.899 & .658 & .884 \\
\hline Customer- to Customers Relationship & 34.0324 & 28.953 & .575 & .889 \\
\hline Trust on Brand & 33.8566 & 26.641 & .735 & .878 \\
\hline Customer's Satisfaction & 33.7913 & 27.230 & .607 & .888 \\
\hline Brand's Effect & 33.7637 & 27.244 & .627 & .886 \\
\hline Attitude Loyalty & 34.0157 & 28.410 & .572 & .889 \\
\hline Behavioral Loyalty & 33.7441 & 27.290 & .728 & .879 \\
\hline
\end{tabular}

According to Table 1, even with the removal of the considered items, the Cronbach Alpha coefficient would be more than 0.7 , which indicates the high reliability of the questionnaire tool.

Analyzing the Data and Testing the Hypotheses In general, the model fitness indicators fall into three main categories: model fit, model matching, and model economics. The general coefficient of structural determination indicates the amount of variation explained in the intrinsic latent variables by the extracted variables. No matter how close this value is, it indicates better fitness of the model. Considering the role that the $\mathrm{K} 2$ statistic plays in fitting models with hidden variables, three other indicators are proposed as methods for comparing alternative models: Toucer luis index (TLI), nonnormalize fit index (NNFI) or normalized (NFI) Benthaler Bount (1987) and comparative fitness Index (CFI).

Table 2.The Model Fitness Indicators

\begin{tabular}{|c|c|c|}
\hline Fitness Indicators & Limit for Fit Indices & The Value obtained from the Model \\
\hline$X^{2}$ & Less than 3 & 2.074 \\
\hline RMSEA & Less than 0.08 & 0.06 \\
\hline PNFI & Greater than 0.5 & 0.805 \\
\hline GFI & Greater than 0.8 & 0.838 \\
\hline AGFI & Greater than 0.8 & 0.803 \\
\hline NFI & Greater than 0.9 & 0.926 \\
\hline TLI & Greater than 0.9 & 0.954 \\
\hline CFI & Greater than 0.9 & 0.960 \\
\hline RFI & Greater than 0.9 & 0.915 \\
\hline IFI & Greater than 0.9 & 0.960 \\
\hline
\end{tabular}

In the study of fitness indicators according to the results of the modified measurement model, we find that our model, fortunately, has fitness, and in all three sections, economic indicators and absolute indicators and comparative indices have reached a good level.

Table 3.Validity and Structural Reliability 


\begin{tabular}{|c|c|c|c|c|c|c|c|c|c|c|c|c|c|c|}
\hline & $\begin{array}{l}\mathbf{C R} \\
\end{array}$ & $\begin{array}{l}\mathbf{A V} \\
\mathbf{E}\end{array}$ & $\begin{array}{l}\text { MS } \\
\text { V }\end{array}$ & $\begin{array}{l}\mathrm{AS} \\
\mathrm{V}\end{array}$ & $\begin{array}{l}\text { Attitu } \\
\text { de } \\
\text { loyalt } \\
y\end{array}$ & $\begin{array}{l}\text { com } \\
\text { munit } \\
\text { y }\end{array}$ & $\begin{array}{l}\text { Custom } \\
\text { er- } \\
\text { product }\end{array}$ & $\begin{array}{l}\text { Brand } \\
\text { custo } \\
\text { mer }\end{array}$ & $\begin{array}{l}\text { Custom } \\
\text { er- } \\
\text { compan } \\
\text { y }\end{array}$ & $\begin{array}{l}\text { Custom } \\
\text { er-other } \\
\text { users }\end{array}$ & $\begin{array}{l}\text { Bra } \\
\text { nd } \\
\text { effe } \\
\text { ct }\end{array}$ & $\begin{array}{l}\text { Bra } \\
\text { nd } \\
\text { Tru } \\
\text { st }\end{array}$ & $\begin{array}{l}\text { Satisf } \\
\text { action }\end{array}$ & $\begin{array}{l}\text { Beha } \\
\text { vioral } \\
\text { loyalt } \\
\text { y }\end{array}$ \\
\hline $\begin{array}{l}\text { Attitude } \\
\text { loyalty }\end{array}$ & $\begin{array}{l}0.85 \\
1\end{array}$ & $\begin{array}{l}0.66 \\
4\end{array}$ & $\begin{array}{l}0.33 \\
6\end{array}$ & $\begin{array}{l}0.19 \\
9\end{array}$ & 0.815 & & & & & & & & & \\
\hline $\begin{array}{l}\text { communi } \\
\text { ty }\end{array}$ & $\begin{array}{l}0.63 \\
8\end{array}$ & $\begin{array}{l}0.75 \\
2\end{array}$ & $\begin{array}{l}0.52 \\
1\end{array}$ & $\begin{array}{l}0.21 \\
2\end{array}$ & 0.467 & 0.867 & & & & & & & & \\
\hline $\begin{array}{l}\text { Customer } \\
\text {-product }\end{array}$ & $\begin{array}{l}0.97 \\
6\end{array}$ & $\begin{array}{l}0.93 \\
2\end{array}$ & $\begin{array}{l}0.63 \\
0\end{array}$ & $\begin{array}{l}0.28 \\
8\end{array}$ & 0.403 & 0.722 & 0.965 & & & & & & & \\
\hline $\begin{array}{l}\text { Brand } \\
\text { customer }\end{array}$ & $\begin{array}{l}0.94 \\
6\end{array}$ & $\begin{array}{l}0.85 \\
5\end{array}$ & $\begin{array}{l}0.40 \\
4\end{array}$ & $\begin{array}{l}0.30 \\
0\end{array}$ & 0.487 & 0.511 & 0.636 & 0.924 & & & & & & \\
\hline $\begin{array}{l}\text { Customer } \\
\text {-company }\end{array}$ & $\begin{array}{l}0.98 \\
2\end{array}$ & $\begin{array}{l}0.94 \\
8\end{array}$ & $\begin{array}{l}0.63 \\
0\end{array}$ & $\begin{array}{l}0.26 \\
8\end{array}$ & 0.366 & 0.623 & 0.794 & 0.615 & 0.973 & & & & & \\
\hline $\begin{array}{l}\text { Customer } \\
\text {-other } \\
\text { users }\end{array}$ & $\begin{array}{l}0.94 \\
4\end{array}$ & $\begin{array}{l}0.84 \\
8\end{array}$ & $\begin{array}{l}0.35 \\
3\end{array}$ & $\begin{array}{l}0.20 \\
8\end{array}$ & 0.427 & 0.463 & 0.594 & 0.576 & 0.497 & 0.921 & & & & \\
\hline $\begin{array}{l}\text { Brand } \\
\text { effect }\end{array}$ & $\begin{array}{l}0.93 \\
5\end{array}$ & $\begin{array}{l}0.78 \\
3\end{array}$ & $\begin{array}{l}0.77 \\
3\end{array}$ & $\begin{array}{l}0.32 \\
5\end{array}$ & 0.451 & 0.307 & 0.430 & 0.627 & 0.450 & 0.440 & $\begin{array}{l}0.88 \\
5\end{array}$ & & & \\
\hline $\begin{array}{l}\text { Brand } \\
\text { Trust }\end{array}$ & $\begin{array}{l}0.98 \\
5\end{array}$ & $\begin{array}{l}0.95 \\
7\end{array}$ & $\begin{array}{l}0.70 \\
1\end{array}$ & $\begin{array}{l}0.23 \\
1\end{array}$ & 0.361 & 0.213 & 0.290 & 0.433 & 0.350 & 0.262 & $\begin{array}{l}0.65 \\
3\end{array}$ & $\begin{array}{l}0.97 \\
8\end{array}$ & & \\
\hline $\begin{array}{l}\text { Satisfacti } \\
\text { on }\end{array}$ & $\begin{array}{l}0.96 \\
6\end{array}$ & $\begin{array}{l}0.85 \\
0\end{array}$ & $\begin{array}{l}0.70 \\
1\end{array}$ & $\begin{array}{l}0.24 \\
7\end{array}$ & 0.432 & 0.198 & 0.288 & 0.426 & 0.360 & 0.308 & $\begin{array}{l}0.67 \\
3\end{array}$ & $\begin{array}{l}0.83 \\
7\end{array}$ & 0.622 & \\
\hline $\begin{array}{l}\text { Behavior } \\
\text { al loyalty }\end{array}$ & $\begin{array}{l}0.96 \\
7\end{array}$ & $\begin{array}{l}0.87 \\
9\end{array}$ & $\begin{array}{l}0.77 \\
3\end{array}$ & $\begin{array}{l}0.30 \\
6\end{array}$ & 0.580 & 0.353 & 0.412 & 0.569 & 0.426 & 0.433 & $\begin{array}{l}0.87 \\
9\end{array}$ & $\begin{array}{l}0.57 \\
7\end{array}$ & 0.592 & 0.938 \\
\hline
\end{tabular}

As can be seen from the table above, the validity and reliability of the structure are verified and there is no problem. Four validity values for factor loads (Factor loads above 0.5, AVE> .5, CR> AVE, MSV <AVE, AEV <USA) as it is seen from the table above, the validity and reliability of the structure are verified and there is no problem. After the relationship between the variables and questions in the form of the model was measured and the validity and reliability of the structure were proven, we are going to the main goal of the research, which is the hypotheses test. The test results are presented in the table below.

Table 4.Considering the Significance of Assumptions

\begin{tabular}{|c|c|c|c|c|c|}
\hline \multicolumn{7}{|c|}{ Table 4.Considering the Significance of Assumptions } \\
\hline $\begin{array}{c}\text { Vustomer-Other } \\
\text { Customers }\end{array}$ & Hypotheses vector & Variable & C.R & P & Result \\
\hline Customer-company & $<---$ & community & 9.026 & Confirm \\
\hline Brand customer & $<---$ & community & 12.772 & $* * *$ & Confirm \\
\hline Customer-product & $<----$ & community & 9.843 & $* * *$ & Confirm \\
\hline Brand Trust & $<---$ & community & 15.215 & $* * *$ & Confirm \\
\hline Brand Trust & $<---$ & $\begin{array}{c}\text { Customer- } \\
\text { company }\end{array}$ & 3.304 & $* * *$ & Confirm \\
\hline Brand Trust & $<---$ & Customer-product & -1.998 & .046 & Confirm \\
\hline Brand Trust & $<---$ & $\begin{array}{c}\text { Customer-Other } \\
\text { Customers }\end{array}$ & .421 & .674 & Reject \\
\hline Brand effect & $<---$ & $\begin{array}{c}\text { Customer- } \\
\text { company }\end{array}$ & 2.316 & .021 & Confirm \\
\hline Brand effect & $<---$ & Brand customer & 8.843 & $* * *$ & Confirm \\
\hline Satisfaction & $<---$ & Brand Trust & 21.379 & $* * *$ & Confirm \\
\hline Brand effect & $<--$ & Customer-product & -1.261 & .207 & Reject \\
\hline Brand effect & $<---$ & $\begin{array}{c}\text { Customer-other } \\
\text { users }\end{array}$ & 2.542 & .011 & Confirm \\
\hline Behavioral loyalty & $<---$ & Brand effect & 17.400 & $* * *$ & Confirm \\
\hline
\end{tabular}




\begin{tabular}{|c|c|c|c|c|c|}
\hline Attitude loyalty & $<---$ & Brand effect & 6.228 & $* * *$ & Confirm \\
\hline Attitude loyalty & $<---$ & Satisfaction & 3.543 & $* * *$ & Confirm \\
\hline Behavioral loyalty & $<---$ & Satisfaction & 1.604 & .109 & Reject \\
\hline
\end{tabular}

From the above table, we denote that assumptions with a significant level of greater than or equal to $\%$ 05 are rejected or, in other words, the load factor of the assumptions within the range of +1.96 and -1.96 is rejected.
The structural model of the research is presented in the figure below.

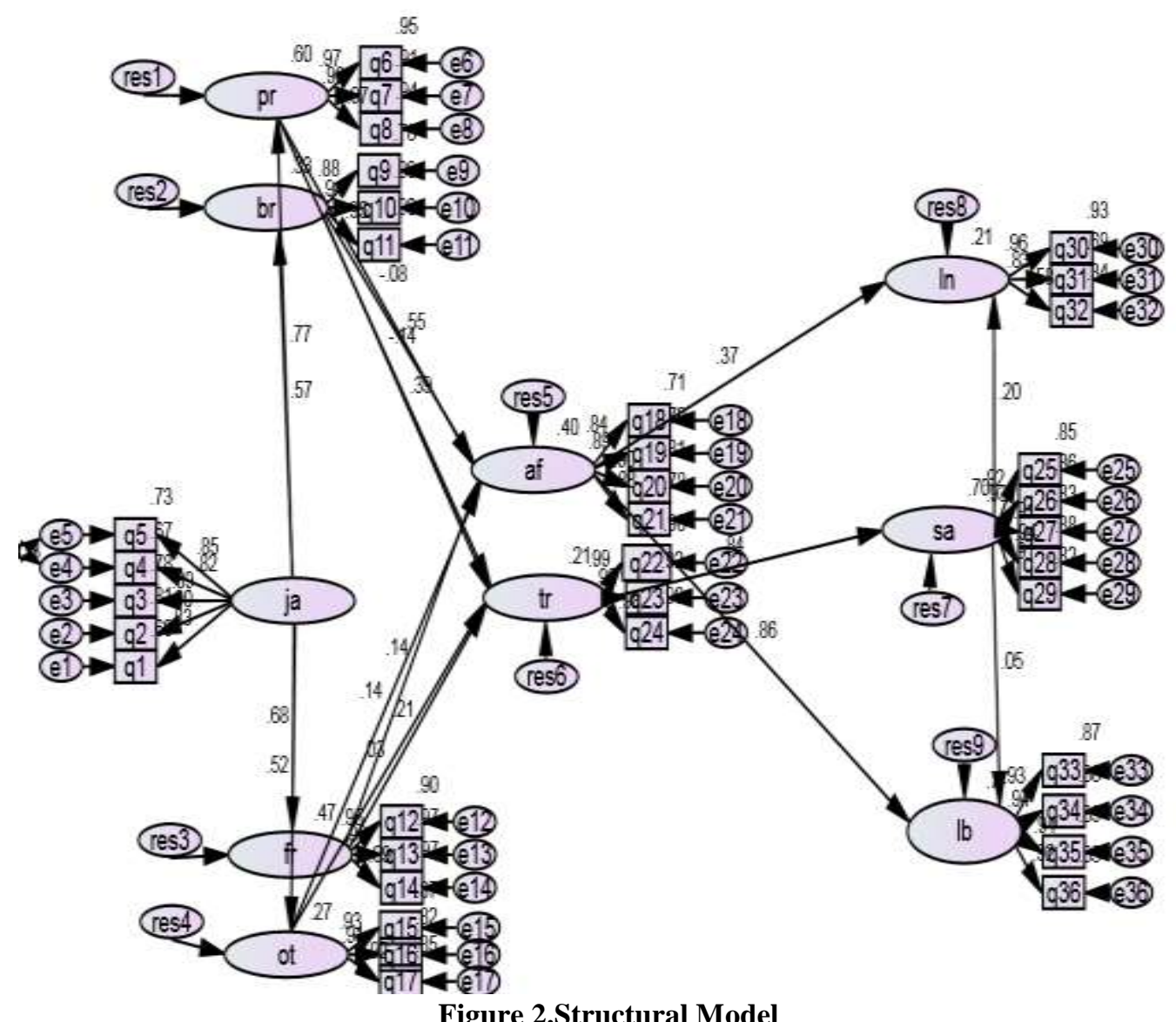

Discussion, Conclusions and Recommendations Research results show that brand community in social networks has a positive and significant effect on customer-product and customer-brand relationship, customer-company relationship, customer-to customer relationship. This means that the content presentation on social networks or the services offering through social networks can strengthen the quadrupled relationships established in previous literature and improve customer and organizational interactions that ultimately create 
strengths points in the organization and gain competitive advantage.

Brand trust can be achieved by consolidating relationships between organizations and customers and managing these relationships to maintain relationships. At the same time, customers will display emotional responses to the brand, which will naturally create trust on brand and loyalty. It should be acknowledged that the rejection of the customerproduct hypothesis by the brand effect can be attributed to the customer's expectations of the product or service that the acquisition or purchase of the product is expected to be supplied and does not cause the customer's emotional feelings.

When the customer -other customers relationship are confirmed by brand effect and trust, it is indicative of the importance of maintaining and supplying the current customer, which cost less than attracting new customer. Confirming this hypothesis, the necessity of paying attention to the impact of individuals on each other and advertising and customer advice is extremely important. We can justify the rejection of the hypothesis of the effect of satisfaction on behavioral loyalty due to a lot of available options to customers and overtaking by competitors. Despite the fact that the customer comes to the brand loyalty and brand recognition, promotional activities and attracting competitors are preventing this cognition and knowledge for the current organization and advise organizations to pay attention to promotional and incentive activities and research and development strategies.

Similar research findings have confirmed the quadruple customer and brand community relationship which is due to customer and organization interactions (8). In addition to the research, the impact of these relationships on trust also contributes to our research. Pérez and Rodriguez del Bosque (45) has shown that the customer-focused activities of the company positively and continuously affect the customer's identification of the banking institutions, customer satisfaction, advice to others, and buying behavior in the sample of Tejarat banks and savings.

The functional implication of this research can be known as the importance of brand community in cyberspace that organizations must be able to achieve socialization and acceptability and competency in this space. Because this universality has benefits to the brand and members can be helpful to the organization as supporter and sponsor services through advice to others. It is also a source of ideas developing and improvement for the Research and Development Unit that can make the organization aware of the change, like the thermostat.
Our suggestion for future research is that one can consider the new concept of community instead of the four-sided relationships of the organization and the customer, and examine its impact by modifying the model via defining cultural relationship with brand community in social networks. Or by placing a commitment and reputation instead of trusting and modifying the model, we can investigate the relationships between customers and brand community and loyalty and by focusing on the results of each of them; we can make an applied research. We can also compare the achieved results in different timeframes and over claim the importance of increasing attention to social network.

\section{Refrences}

1.Kamboj S, Rahman Z. The influence of user participation in social media-based brand communities on brand loyalty: age and gender as moderators. Journal of Brand Management. 2016;23(6):679-700.

2.Zehir C, Şahin A, Kitapçı H, Özşahin M. The effects of brand communication and service quality in building brand loyalty through brand trust; the empirical research on global brands. Procedia-Social and Behavioral Sciences. 2011;24:1218-31.

3.Shirin A, Puth G. Customer satisfaction, brand trust and variety seeking as determinants of brand loyalty. African Journal of Business Management. 2011;5(30):11899.

4.Møller Jensen J, Hansen T. An empirical examination of brand loyalty. Journal of Product \& Brand Management. 2006;15(7):442-9.

5.Geçti F, Zengin $\mathrm{H}$. The relationship between brand trust, brand affect, attitudinal loyalty and behavioral loyalty: A field study towards sports shoe consumers in Turkey. International Journal of Marketing Studies. 2013;5(2):111.

6.Chaudhuri A, Holbrook MB. The chain of effects from brand trust and brand affect to brand performance: the role of brand loyalty. Journal of marketing. 2001;65(2):81-93.

7.Kabadayi ET, Alan AK. Brand trust and brand affect: Their strategic importance on brand loyalty. Journal of Global Strategic Management. 2012;11(6):81-8.

8.Handayani PW, editor Analysis on effects of brand community on brand loyalty in the social media: A case study of an online transportation (UBER). Advanced Computer Science and Information Systems (ICACSIS), 2016 International Conference on; 2016: IEEE.

9.Maurya UK, Mishra P. What is a brand? A Perspective on Brand Meaning. European Journal of Business and Management. 2012;4(3):122-33.

10.Wang J. The relationship between brand association and brand equity in the brand relationship management. International Research Journal of Arts and social Science. 2015;1(4):1-6. 
11.Murtiasih S, Siringoringo H. How word of mouth influence brand equity for automotive products in Indonesia. Procedia-Social and Behavioral Sciences. 2013;81:40-4.

12.Iş1k F. Comparison of the use of social network in education between North and South Cyprus. Procedia-Social and Behavioral Sciences. 2013;103:210-9.

13.Othman MS, Suhaimi SM, Yusuf LM, Yusof N, Mohamad N. An analysis of social network categories: social learning and social friendship. Procedia-Social and Behavioral Sciences. 2012;56:441-7.

14.Tadeu P, Lucas J. Social network in education: a mathematical pilot test. Procedia-Social and Behavioral Sciences. 2013;106:2409-18.

15.Bicen H. Determination of University Students' Reasons Ofusing Social Networking Sites in their Daily Life. Procedia-Social and Behavioral Sciences. 2015;190:519-22.

16.Cao J, Knotts T, Xu J, Chau M. Word of mouth marketing through online social networks. AMCIS 2009 Proceedings. 2009:291.

17.Laud G, Mulye R, Rahman K, editors. Use of embedded brand community networks for brand cocreation. ANZMAC 2011; 2011: Australian and New Zealand Marketing Academy.

18.Jha B. . Social Media, Brand Community, User generated comments and Brand Loyalty: Study of Indian Youth. Journal of Business and Management. 2014;16(10):122-31.

19.Hossain S, Sakib MN. The Impact of Social Media Marketing on University Students' Brand Loyalty. International Journal of Marketing \& Business Communication. 2016;5(3).

20.Hameed F. The effect of advertising spending on brand loyalty mediated by store image, perceived quality and customer satisfaction: A case of hypermarkets. Asian Journal of Business Management. 2013;5(1):181-92.

21.Davcik NS, da Silva RV, HAIR J. Towards a unified theory of brand equity: Conceptualizations, typologies and avenues for future research. Business Research Unit Instituto Universitário de Lisboa, Working Paper 14. 2014;2:14-02.

22.Munnukka J, Karjaluoto H, Tikkanen A. Are Facebook brand community members truly loyal to the brand? Computers in Human Behavior. 2015;51:429-39.

23.Resnick M. Increasing brand equity with interactive, on-line communities. Journal of EBusiness. 2001;1(2):1-6.

24.McAlexander JH, Schouten JW, Koenig HF. Building brand community. Journal of marketing. 2002;66(1):38-54.

25.Muniz AM, O'guinn TC. Brand community. Journal of consumer research. 2001;27(4):412-32. 26.Nambisan S, Baron RA. Virtual customer environments: testing a model of voluntary participation in value co-creation activities. Journal of product innovation management. 2009;26(4):388406.

27.Zhou Z, Zhang Q, Su C, Zhou N. How do brand communities generate brand relationships? Intermediate mechanisms. Journal of Business Research. 2012;65(7):890-5.

28.Füller J, von Hippel EA. Costless creation of strong brands by user communities: Implications for producer-owned brands. 2008.

29.Wu J, Fan S, Wu M, Zhao JL, editors. Formation and effect of Social Interactions in Online Brand Community: an Empirical Investigation. PACIS; 2014.

30.Agustin C, Singh J. Curvilinear effects of consumer loyalty determinants in relational exchanges. Journal of marketing research. 2005;42(1):96-108.

31.Laroche M, Habibi MR, Richard M-O, Sankaranarayanan R. The effects of social media based brand communities on brand community markers, value creation practices, brand trust and brand loyalty. Computers in Human Behavior. 2012;28(5):1755-67.

32.Cheung CM, Thadani DR. The impact of electronic word-of-mouth communication: A literature analysis and integrative model. Decision support systems. 2012;54(1):461-70.

33.Deng Z, Lu Y, Wei KK, Zhang J. Understanding customer satisfaction and loyalty: An empirical study of mobile instant messages in China. International journal of information management. 2010;30(4):289-300.

34.Brogi S, Calabrese A, Campisi D, Capece G, Costa R, Di Pillo F. The effects of online brand communities on brand equity in the luxury fashion industry. International Journal of Engineering Business Management. 2013;5:32.

35.Matzler $\mathrm{K}$, Bidmon S, Grabner-Kräuter S. Individual determinants of brand affect: the role of the personality traits of extraversion and openness to experience. Journal of Product \& Brand Management. 2006;15(7):427-34.

36.Taylor SA, Celuch K, Goodwin S. The importance of brand equity to customer loyalty. Journal of product \& brand management. 2004;13(4):217-27.

37.Jahangir N, Parvez, N., Bhattacharjee, D., \& Ahamed, K. K. . The relationship between brand affect. 2009.

38.Singh J, Sirdeshmukh D. Agency and trust mechanisms in consumer satisfaction and loyalty judgments. Journal of the Academy of marketing Science. 2000;28(1):150-67.

39.Choi YG, Ok C, Hyun SS. Evaluating relationships among brand experience, brand personality, brand prestige, brand relationship quality, and brand loyalty: an empirical study of coffeehouse brands. 2011. 
40.Bolton RN. A dynamic model of the duration of the customer's relationship with a continuous service provider: The role of satisfaction. Marketing science. 1998;17(1):45-65.

41.Wilson A, Persson N. The Interplay Between Brand Loyalty and Brand Satisfaction: A qualitative study of consumers in the clothing industry. 2017. 42.Bennur S, Jin B. The mediating role of brand trust and affect in clothing brand loyalty formation: a cross-cultural examination of US and India. The Journal of The Textile Institute. 2017;108(1):1-9.
43.Anderson RE, Srinivasan SS. E-satisfaction and e-loyalty: A contingency framework. Psychology \& marketing. 2003;20(2):123-38.

44.Jin N, Line ND, Merkebu J. The impact of brand prestige on trust, perceived risk, satisfaction, and loyalty in upscale restaurants. Journal of Hospitality Marketing \& Management. 2016;25(5):523-46.

45.Pérez A, Rodriguez del Bosque I. Corporate social responsibility and customer loyalty: exploring the role of identification, satisfaction and type of company. Journal of Services Marketing. 2015;29(1):15-25. 